\title{
Turkish glacier inventory and classification from high-resolution satellite data
}

\author{
Roberto Sergio Azzoni ${ }^{1} \cdot$ Mehmet Akif Sarıkaya $^{2} \cdot$ Davide Fugazza $^{1}$
}

Received: 25 February 2020 / Revised: 14 April 2020 / Accepted: 15 April 2020 / Published online: 28 April 2020

(c) Springer Nature Switzerland AG 2020

\begin{abstract}
In view of the rapid and accelerating glacier retreat observed worldwide, the creation of an updated glacier inventory is fundamental to understand the glacier changes. Here we present the Turkish glacier inventory based on recent high-resolution satellite images (Pleiades, Google Earth ${ }^{\mathrm{TM}}$ and SPOT images). Outlines are manually digitized in ArcMap software. We identified 51 glaciers covering $12.29 \mathrm{~km}^{2}$ : more than $60 \%$ of the Turkish glacierized area is located on Mount Ararat where the ice cap and four small outlet glaciers cover $7.37 \mathrm{~km}^{2}$. Turkish glaciation is characterized by small glaciers or glacierets partly debris-covered: only three glaciers (Erinç, Izbırak and Ararat glaciers) are larger than $0.5 \mathrm{~km}^{2}$. To assess the evolution of glaciers, we have focused on Mount Ararat where we digitized outlines for 1990, 1994, 2000 and 2016: in 26 years considered the glacier shows a retreat of $2.99 \mathrm{~km}^{2},-29 \%$ of the initial value, showing a reduction rate dramatically higher than the main glacierized mountain ranges of the world.
\end{abstract}

Keywords Glacier inventory $\cdot$ Remote sensing $\cdot$ Turkey $\cdot$ Pleiades

\section{Introduction}

Glaciers are key indicators of climate change, quickly responding to the present temperature warming (IPCC 2013). In this context, frequent updates of glacier inventories are fundamental for downstream hydrology and its present and future modelling (Immerzeel et al. 2010), in particular in the Mediterranean area where the climate is characterized by frequent summer droughts (Giorgi and Lionello 2008). Despite their unfamiliarity, glaciers do exist in Turkey and are located on the summits of the highest coastal mountains (e.g. Taurus) and on three interior stratovolcanoes (Mt. Ararat, Mt. Erciyes and Mt. Süphan) (Williams and Ferrigno 1998). The first modern studies on Turkish glaciers were performed by Erinç (1952) who reported detailed information about the glaciation of Mount Erciyes, Cilo Region and Eastern Pontic Mountains, and Blumenthal (1958) who investigated mainly

Roberto Sergio Azzoni

robertosergio.azzoni@unimi.it

1 Dipartimento di Scienze e Politiche Ambientali, Università degli Studi di Milano, Via Celoria 2, 20133 Milan, Italy

2 Eurasia Institute of Earth Sciences, Istanbul Technical University, Sariyer, Istanbul, Turkey
Mount Ararat (locally known as Mt. Ağrı) but also the ice bodies of the Aladağlar and Kaçkar Mountains. A first overview of the whole Turkey glaciation, based on reconnaissance field work and photographic analysis was reported by Birman (1968) and later by Horvath (1975). The increased availability of remote-sensing data led to the compilation to the first atlas of Turkish glaciers (Williams and Ferrigno 1998) based on Landsat imagery collected between 1975 and 1980: they reported a total area of 22.9 $\mathrm{km}^{2}$ for Turkish glaciers, mainly located on Mount Ararat $\left(10 \mathrm{~km}^{2}\right)$, Mount Uludoruk $\left(8 \mathrm{~km}^{2}\right)$ and Mount Süphan (3 $\mathrm{km}^{2}$ ). Hughes (2014) reviewed the glacier extent in the Mediterranean area and presented ice surface variation since the Little Ice Age for selected Turkish glaciers based on geomorphologic evidence. More recently Sarıkaya and Tekeli (2014) developed an updated Turkish glacier inventory from ASTER (Advanced Spaceborne Thermal Emission and Reflection Radiometer) imagery (obtained from 2003 to 2011; 15 m resolution) supported by Google Earth $^{\mathrm{TM}}$ imagery, describing 17 mountain glaciers, 1 ice cap and 33 glacierets covering $11.52 \mathrm{~km}^{2}$. Yavaşlı et al. (2015) investigated the evolution of Turkish glaciation from the 1970s to 2012-2013 and found that the area of Turkish glaciers decreased from $25 \mathrm{~km}^{2}$ in the 1970s to $10.85 \mathrm{~km}^{2}$ in 2012-2013. Some authors have investigated 
the glaciation of a single mountain range: namely, the extent and evolution of Mt. Ararat glacier was analyzed in detail by Sarıkaya (2012); and Azzoni et al. (2017, 2019).

Considering the characteristics of Turkish glaciation, which is mainly characterized by small glaciers and glacierets located in mountain cirques, high-resolution imagery is mandatory for a correct identification of glacier outlines, especially in the presence of supraglacial debris or snow patches. The analysis of recent high-resolution remote sensing images from Pleiades ( $0.5 \mathrm{~m}$ pixel resolution) and SPOT 6 and 7 (1.5 m resolution) satellites can provide new insights into the characteristics and evolution of small glaciers as reported by Berthier et al. (2014), Holzer et al. (2015) and Ruiz et al. (2015). Further still, new findings on Mount Ararat glacier based on field activities (Azzoni et al. 2017, 2019) suggested the need for an update of Turkish glacier inventories. In this study, we present an updated, high-resolution Turkish glacier inventory and classification based on Pleiades and SPOT data obtained between 2016 and 2017, focusing on the geomorphological characteristics of glaciers. Moreover, we assess the evolution of Mt. Ararat glacier, the most representative glacierized area of Turkey, over the last 30 years, in the light of new considerations about the glaciation of this area reported by Azzoni et al. (2017, 2019).

\section{Study area}

Turkey is located in the Eastern Mediterranean region between $36^{\circ}$ and $42^{\circ} \mathrm{N}$ and $26^{\circ}$ and $45^{\circ} \mathrm{E}$. It has an average elevation of $1.140 \mathrm{~m}$ a.s.l. (above sea level), higher in the Eastern part where Mount Ararat (5137 m a.s.l.) reaches the highest point of the country. The region is characterized by the influence of the temperate Mediterranean climate and mid-latitude subtropical high-pressure systems ( $\mathrm{La}$ Fontaine et al. 1990). Precipitation in Turkey is affected by the local topography, ranging from less than $400 \mathrm{~mm}$ per year in Central Anatolia and in the Easternmost part of the region to more than $2200 \mathrm{~mm}$ per year in the Eastern part of the Black Sea (Türkeş and Erlat 2005). In view of these orographic and climatic characteristics, glaciers are located only on the highest peaks of coastal ranges (Bolkar Mountains, Aladağlar, Eastern Black Sea Mountains) and current glaciation is mostly characterized by small glacierets or perennial snow patches (Gürgen et al. 2010; Çalışkan et al. 2014; Bayrakdar et al. 2015). Towards the eastern part of Turkey, the elevation of the snowline increases in association with enhanced continentality (Kurter 1991). Indeed, the southeastern part of the Taurus Mountains presents a relatively large number of glaciers. Moreover ice is also found on individual stratovolcanoes: Mount Ararat is covered by an ice cap while the flanks of Mt. Süphan host small glaciers (Fig. 1).

\section{Methods}

\section{Image data}

We analyzed 8 different Pleiades images of Turkish glacierized area acquired in 2016 and in 2017 (0.5 m spatial resolution; see details in Table 1) choosing summer scenes to reduce the probability of snow and cloud cover and minimize the occurrence of shadows. In the Eastern Black Sea Mountain area, we used SPOT 6 and SPOT 7 imagery at a slightly lower resolution $(1.5 \mathrm{~m})$ due to the lack of suitable Pleiades images. We also performed a detailed analysis of the Mount Ararat glacier employing multitemporal SPOT (1990, 1994 with a $10 \mathrm{~m}$ spatial resolution and 2000 with $1.5 \mathrm{~m}$ spatial resolution), Google Earth ${ }^{\mathrm{TM}}(2010-3.5 \mathrm{~m}$ spatial resolution) and Pleiades images (2016).

\section{Topographic data}

We downloaded six $1^{\circ} \times 1^{\circ}$ tiles from the AW3D30 product, a global DEM generated from ALOS PRISM data (Takaku et al. 2016). While the DEM is initially produced at $5 \mathrm{~m}$, we obtained the free downsampled version at 30-m resolution from JAXA (Japan aerospatial agency). Earlier glacier inventories have used the SRTM or ASTER GDEM (Paul et al. 2011; Sarıkaya and Tekeli 2014); in contrast, we chose the AW3D30 because of its closer temporal match to our inventory date compared to SRTM and better quality and accuracy compared to the ASTER GDEM. As concerns the acquisition date, tiles covering the study area were generated by merging raw data acquired between 2006 and 2011. As regards accuracy, the tile metadata report deviations from SRTM, ASTER and ICESAT, and the root mean square error compared to ICESAT ranges between $2 \mathrm{~m}$ and $3.66 \mathrm{~m}$ for the selected tiles. These were merged together and topographic parameters including minimum, maximum, mean and median elevation, elevation range, average slope and aspect were derived following recommendations by Paul et al. (2009). Additionally, we reclassified the DEM into $50 \mathrm{~m}$ elevation bins to calculate the glacier hypsography.

\section{Glacier limits delimitation}

The outline of each glacier was manually digitized in Arc Map software. The high-resolution satellite images featured low or absent cloud coverage and were acquired when snow cover was at a minimum; thus, glacier outlines are clearer and can be better detected. Ice bodies featuring a surface area smaller than $0.01 \mathrm{~km}^{2}$ were not considered in this inventory: this threshold is suggested by international literature dealing with glacier inventories (GLIMS project and among others, 


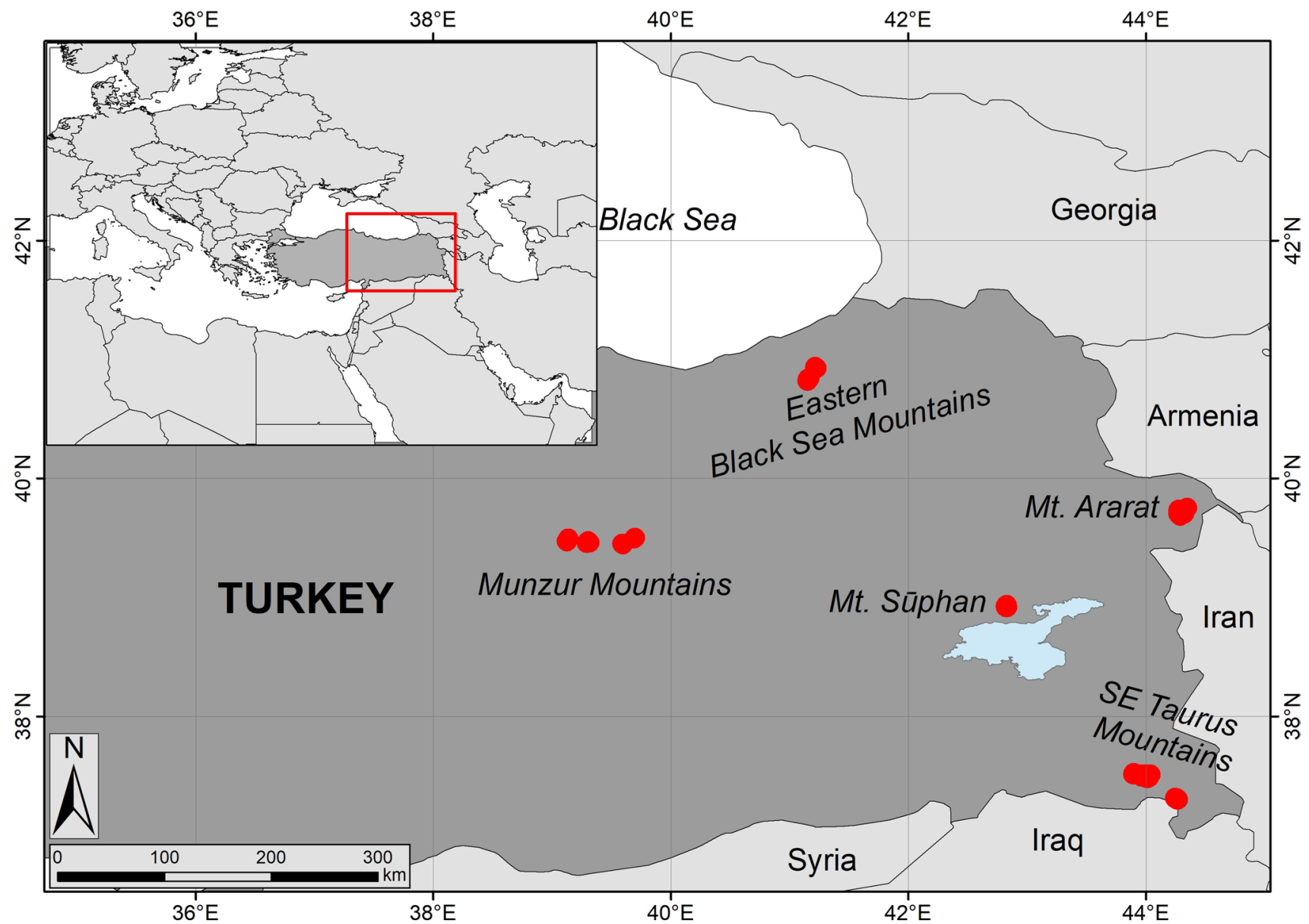

Fig. 1 Location of Turkish glaciers in five different mountain groups

Table 1 Satellite Images and DEM tiles used in the production of the Turkish Glacier Inventory

\begin{tabular}{lll}
\hline Satellite product & Date of acquisition & Resolution (m) \\
\hline SPOT 6 PMS & 9 Sept 2016 & 1.5 \\
Pleiades PHR 1B PMS & 4 Sept 2016 & 0.5 \\
Pleiades PHR 1B PMS_ & 10 Sept 2017 & 0.5 \\
Pleiades PHR 1A PMS & 10 Sept 2016 & 0.5 \\
Pleiades PHR 1B PMS_ & 7 Sept 2016 & 0.5 \\
Pleiades PHR 1A PMS & 27 Aug 2016 & 0.5 \\
Pleaides PHR 1B PMS_ & 23 Aug 2016 & 0.5 \\
Pleiades PHR 1B PMS & 20 Oct 2017 & 0.5 \\
Pleiades PHR 1B PMS_ & 7 Sept 2016 & 0.5 \\
SPOT 7 PMS & 4 Oct 2016 & 1.5 \\
AW3D N37E43 & 2006-2011 & 30 \\
AW3D N37E44 & 2006-2011 & 30 \\
AW3D N38E42 & 2006-2011 & 30 \\
AW3D N39E39 & 2006-2011 & 30 \\
AW3D N39E44 & 2006-2011 & 30 \\
AW3D N40E41 & 2006-2011 & 30 \\
\hline
\end{tabular}

Paul et al. 2009). From the analysis of satellite images, we also derived information on glacier aspect and type (following the recommendations by Paul et al. 2009). To assess the potential error affecting data, the approach introduced by Vögtle and Schilling (1999) was followed. This method, largely applied in the recent past to evaluate the error in glacier area (Smiraglia et al. 2015), is based on the calculation of the surface area buffer for each mapped glacier. Thanks to the high quality and resolution of the orthophotos and to the accurate manual mapping, we estimated an error lower than $\pm 2 \%$ of the actual value for the obtained glacier area.

\section{Glacier inventory parameters}

We followed the World Glacier Monitoring Service (WGMS) guidelines to compile the Turkish Glacier Inventory (Paul et al. 2009). The parameters derived are: identification code (ID); coordinates; source used and acquisition date; planimetric surface area $\left(\mathrm{km}^{2}\right)$; maximum length (m); minimum, maximum, mean, and median elevation (m, a.s.l.); mean aspect. Topographic parameters were calculated 
Table 2 List of Turkish glacier divided in five main mountain groups

\begin{tabular}{llc}
\hline Mountain group & Number of glaciers & Area $\left(\mathrm{km}^{2}\right)$ \\
\hline Munzur mountains & 12 & 0.31 \\
$\begin{array}{l}\text { South Eastern Taurus Moun- } \\
\text { tains (Buzul Mts.) }\end{array}$ & 29 & 3.82 \\
Mt. Süphan & 3 & 0.20 \\
$\begin{array}{l}\text { Eastern Black Sea Mountains } \\
\quad \text { Kaçkar Mts.) }\end{array}$ & 6 & 0.58 \\
Mt. Ararat & 1 & 7.37 \\
Turkey & 51 & 12.29 \\
\hline
\end{tabular}

using the AW3D DEM. The length was calculated manually by digitizing the main glacier flowline.

\section{Results}

\section{Present Turkey glaciation}

In Turkey, we identified 51 ice bodies covering $12.29 \mathrm{~km}^{2}$ (Table 2). More than $60 \%$ of the Turkish glacierized area is located on Mount Ararat where the ice cap and four small outlet glaciers cover $7.37 \mathrm{~km}^{2}$. Glaciers are present in 5 different areas of Turkey: in addition to the main ice cap, 12 glaciers are present on Munzur Mountains (covering $\left.0.31 \mathrm{~km}^{2}\right), 29$ glaciers are located on South Eastern Taurus Mountains (Buzul Mountains) (covering $3.82 \mathrm{~km}^{2}$ ), 3 ice bodies are located on Mount Süphan (covering $0.20 \mathrm{~km}^{2}$ ) and six glaciers are located on the Eastern Black Sea Mountains (Kaçkar Mountains) (covering $0.58 \mathrm{~km}^{2}$ ). We did not consider the glacier located on the slope of the Mount Erciyes, described in Sarıkaya et al. (2009), because its area is now smaller than $0.01 \mathrm{~km}^{2}$, a typical threshold used in the regional glacier inventories (Paul et al. 2009). It was 0.05 $\mathrm{km}^{2}$ in August 2008 (Sarıkaya et al. 2009).

\section{Distribution of glaciers according to size classes}

The size class of Turkish glaciers ranged from 0.01 to 7.37 $\mathrm{km}^{2}$ on Mount Ararat ice cap (Fig. 2): two small glacierets described in the Randolph Glacier Inventory (Pfeffer et al. 2014) and perennial snow patches were not taken into account in this inventory. The mean glaciers size is $0.24 \mathrm{~km}^{2}$ but $76 \%$ of the ice bodies are smaller than $0.1 \mathrm{~km}^{2}$ and $94 \%$ of glaciers have a surface lower than $0.5 \mathrm{~km}^{2}$. Only three glaciers (Erinç, Izbırak and Ararat glaciers) are larger than $0.5 \mathrm{~km}^{2}$. According to size class and glacier morphology and excluding the Ararat ice cap, most of the glaciers (i.e. 42) are classified as glacierets and eight glaciers are classified as mountain glaciers.

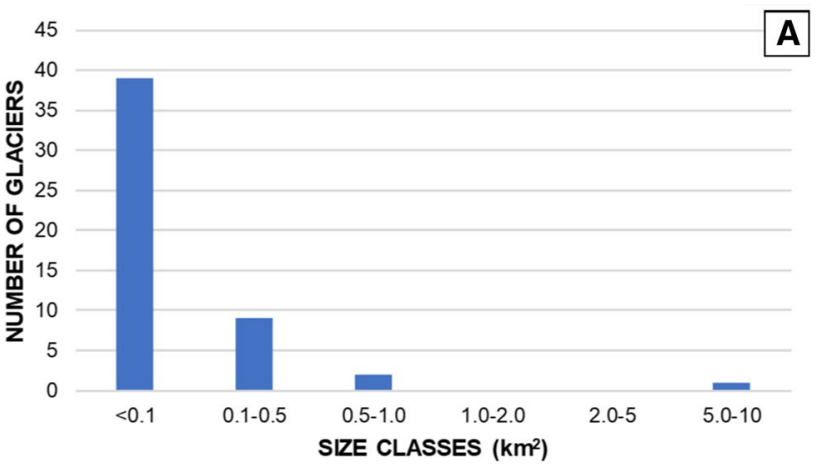

B

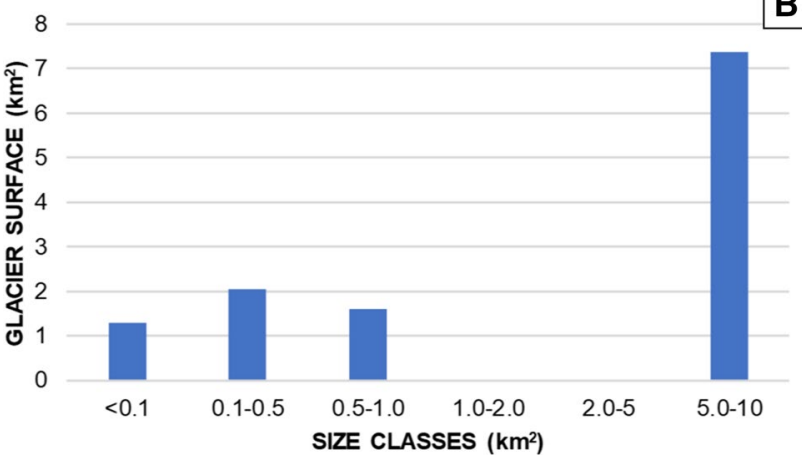

Fig. 2 a Number frequency distribution and $\mathbf{b}$ surface area frequency distribution of the Turkish glaciers. Glaciers were sorted according to six size classes

\section{Distribution of glaciers according to aspect}

The distribution of Turkish glaciers according to their aspect is largely influenced by the Mount Ararat glacier. In fact, considering the number of glaciers, ice bodies are mainly oriented northward: 27 ice bodies face north, 13 ice bodies flow toward northeast and 7 glaciers have a northwestern orientation (Fig. 3). Considering the distribution of glacierized surface area according to aspect, $83 \%$ of the whole glacier area is oriented northward: this value is caused by the influence of the Mount Ararat Glacier, which has a mean aspect of $349^{\circ}$ (North). If we exclude Mt. Ararat, the main aspect will be North East.

\section{Distribution of glaciers according to elevation variables}

The 51 Turkish glaciers have a wide altimetric range (Fig. 4). The average elevation is $3282 \mathrm{~m}$ a.s.l. The lowest elevation ( $2211 \mathrm{~m}$ a.s.l.) is reached by the North-Western tongue flowing from the Mt. Ararat ice cap. This ice tongue is buried by a thick debris cover, which prevents melting of the underlying ice. Mt. Ararat has also the maximum elevation among Turkish glaciers (5137 $\mathrm{m}$ a.s.1.), which roughly corresponds to the summit of the mountain. 


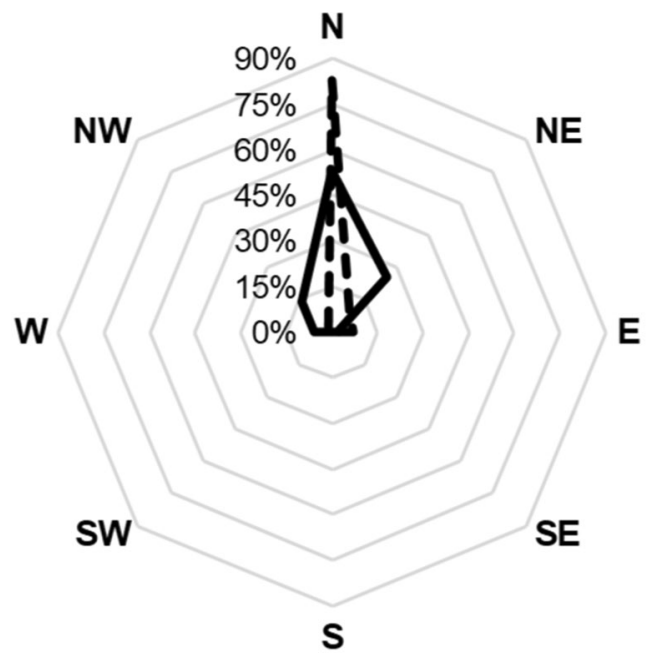

Number of glacier $\quad$ - - Glacier Area

Fig. 3 Distribution of the number and surface area of Turkish glaciers according to their aspects

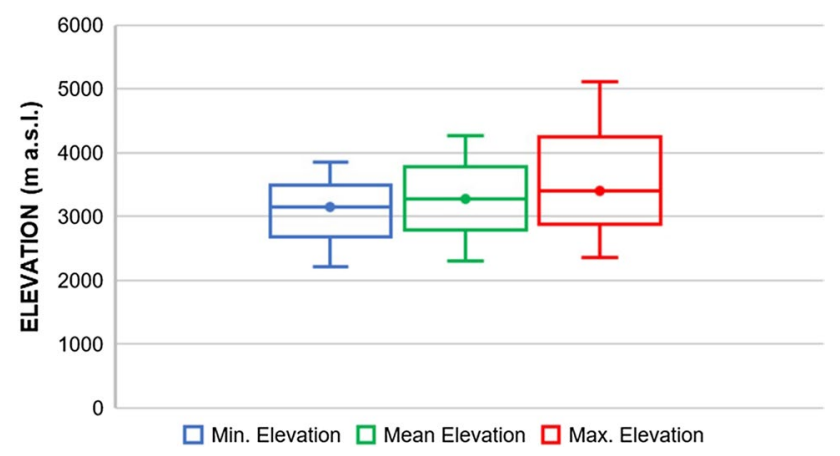

Fig. 4 Boxplots of minimum, mean, and maximum elevations of the Turkish glaciers

The size of Mount Ararat glacier compared to the other smaller glaciers is also reflected in its importance in the overall glacier hypsography (Fig. 5). For the small glaciers, elevation ranges between $2750 \mathrm{~m}$ a.s.l. and $3950 \mathrm{~m}$ a.s.l. Conversely, Mt. Ararat glacier has a large part of its area at $4700 \mathrm{~m}$ a.s.l., although the large elevation range of this glacier shows that there is contribution from all elevation bins.

\section{Distribution of glaciers according to length}

The maximum length of glaciers, obtained from a manual definition of the main flowline, highlights the same consideration obtained from the other glacier parameters: $80 \%$ of Turkish ice bodies are shorter than $500 \mathrm{~m}$ and $92 \%$ of glaciers has a flowline lower than $1 \mathrm{~km}$ (Fig. 6). The longest Turkish glacier is on Mt. Ararat: from the peak of the mountain (5137 $\mathrm{m}$ a.s.1.) to the snout of the Cehennem ice flow (2193 $\mathrm{m}$ a.s.l.), the flowline is $7860 \mathrm{~m}$.

\section{Mt. Ararat glaciers}

The glacierized area of Mt. Ararat can be classified as an ice cap; however, we identified four main ice bodies flowing downward from the summit plateau. Three ice bodies, that correspond to the Parrot Glacier, on the Northwest flank, the Cehennem Glacier (Azzoni et al. 2019), on Northeastern flank of the mountain, and the Parachute Glacier on the Southwest side of the mountain, are characterized by a thick debris cover, which strongly influences surface melting and glacier evolution. The summit ice cap consists of two separated flat areas: the Western Plateau, located under the summit at about $4700 \mathrm{~m}$ a.s.l., and the Heyelan Plateau, located on the Northern side of the glacierized area at $4300 \mathrm{~m}$ a.s.l. The ice cap features a regular topography, without wide crevassed areas. Multitemporal medium and high-resolution data permit to investigate the evolution of Mt. Ararat glaciation from 1990 to 2016 (Table 3) The ice cap retreated from $10.35 \mathrm{~km}^{2}$ in 1990 to $7.36 \mathrm{~km}^{2}$ in 2016 , as reported in Table 3 . In 26 years, the glacier retreated by $2.99 \mathrm{~km}^{2}$ losing $29 \%$ of the initial area.

\section{Discussion}

\section{Characteristics of Turkish glaciers}

The Turkish glaciation is characterized by two very different faces: a wide ice-cap located in the Eastern part of the country, on the top of the Mt. Ararat, and numerous small mountain glaciers or glacierets ( 50 glacier with a mean surface of $0.10 \mathrm{~km}^{2}$ ) located in four different mountain groups. These latter have the typical characteristic of Mediterranean ice bodies or glacierets like those that can be found in the Pyrenees (France, Spain and Andorra), Maritime Alps (France and Italy), Apennines (Italy), Julian Alps (Italy and Slovenia), Tatra Mountains (Slovakia), Dinaric and Albanian Alps (Montenegro, Albania and Bosnia) and Pirin Mountains (Bulgaria), as reported by Hughes (2014). In these mountainous regions, glaciers cover few square kilometers. In the Pyrenees, glaciers cover $5.25 \mathrm{~km}^{2}$ (Gardent et al. 2014; Gonzales-Trueba et al. 2008), on Maritime Alps only three small glacierets are present on the French side (Gardent et al. 2014) and six glaciers covering $0.41 \mathrm{~km}^{2}$ survive on the Italian side (Diolaiuti et al. 2019). The Apennines are characterized by two small glacierets covering 0.04 $\mathrm{km}^{2}$ (Diolaiuti et al. 2019). In the On Julian Alps ice covers $0.30 \mathrm{~km}^{2}$ (Diolaiuti et al. 2019). The other ice bodies in Slovakia, Albania, Montenegro, Bosnia and Bulgaria cover in total less than $0.20 \mathrm{~km}^{2}$ (Diolaiuti et al. 2019). 


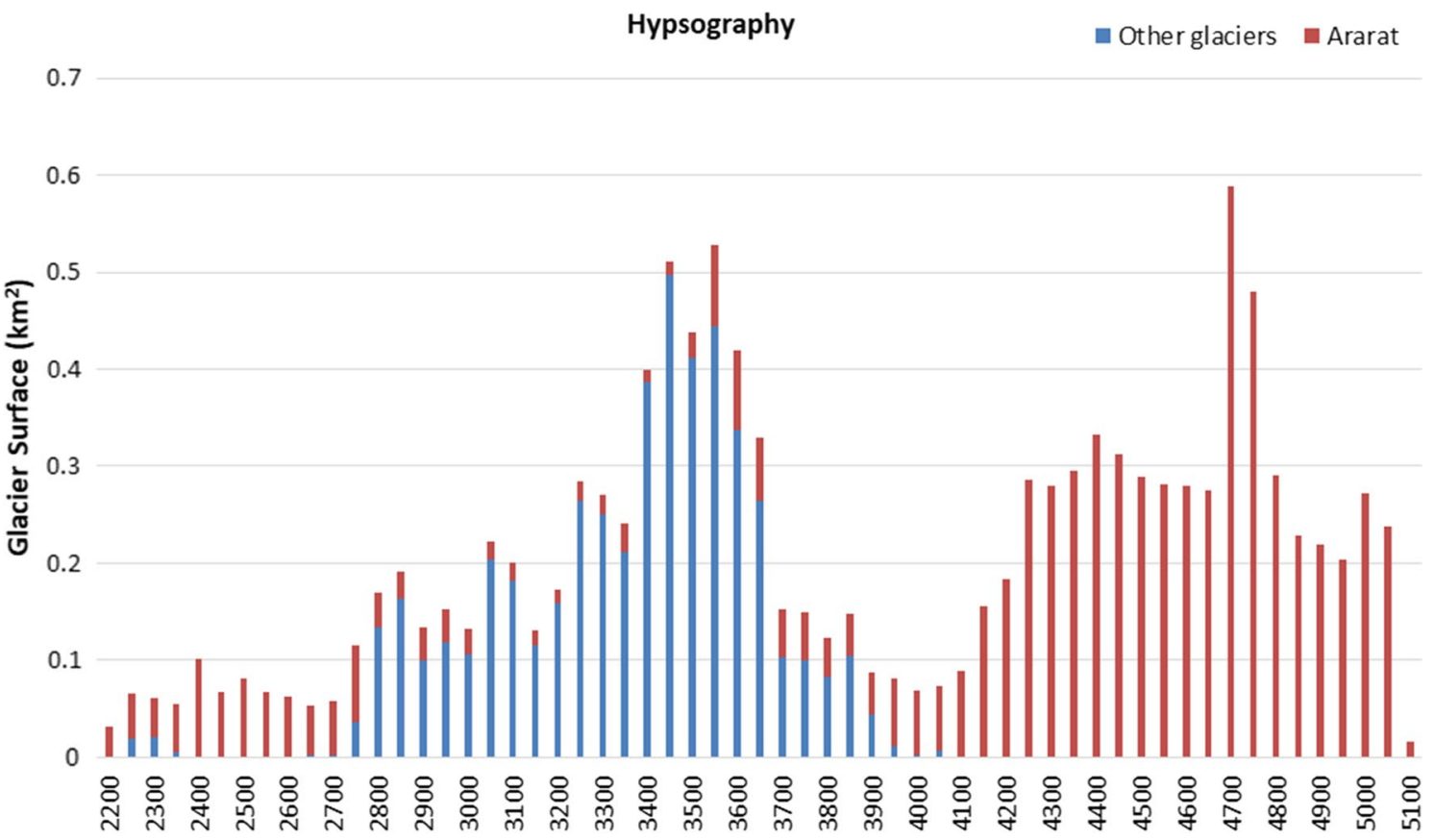

Elevation (m a.s.I.)

Fig. 5 Hypsography of Turkish glaciers in 50 m elevation bins. The graph shows separate series for Mount Ararat and all the other glaciers

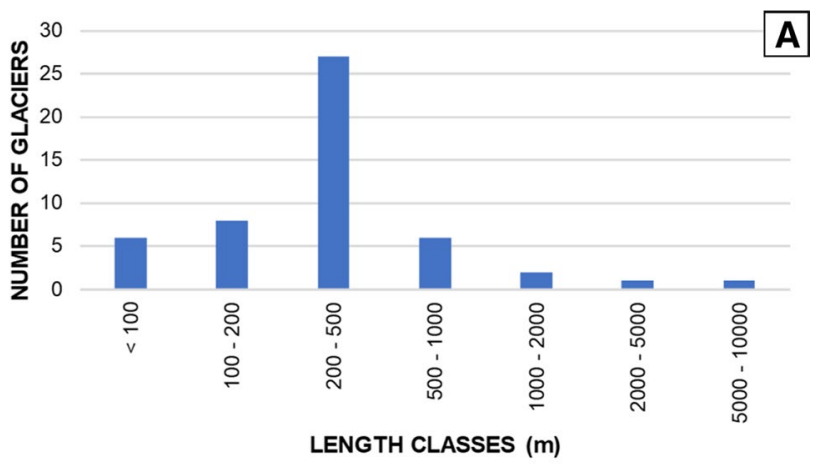

B

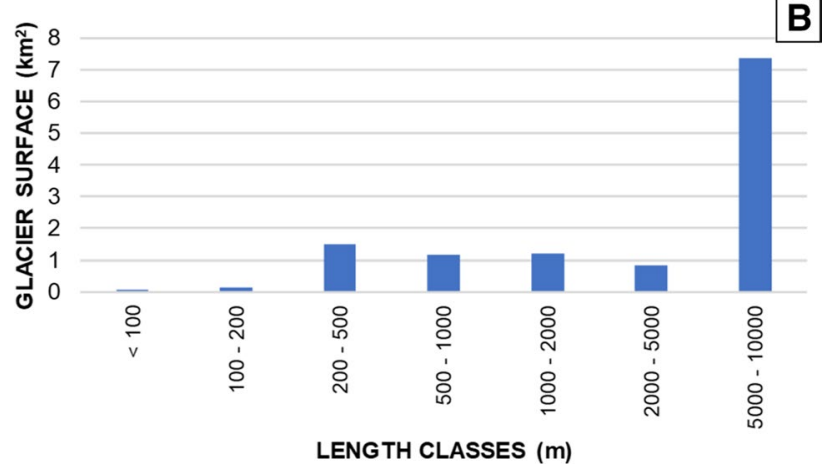

Fig. 6 a Number frequency distribution and $\mathbf{b}$ surface area frequency distribution of the Turkish glaciers
Table 3 Mt. Ararat glacier evolution in the timeframe 1990-2016

\begin{tabular}{llc}
\hline Year & Source & Area $\left(\mathrm{km}^{2}\right)$ \\
\hline 1990 & SPOT 1 & 10.35 \\
1994 & SPOT 3 & 9.55 \\
2000 & SPOT 4 & 8.72 \\
2010 & Google Earth & 7.28 \\
2016 & Pleiades & 7.36 \\
\hline
\end{tabular}

Glaciers and glacierets survive in niche localities thanks to their local topoclimatic controls, such as avalanching or windblown snow, which can increase accumulation (Hughes 2009). Many ice bodies present a wide debris cover and in many cases debris supply from surrounding rock walls (Azzoni et al. 2018) exceeds snow accumulation leading to the formation of wide patches of buried ice and, eventually, the formation of a rock glacier if the ice-debris mass is able to move and flow down-valley (Hughes 2014). Considering the classification of the ice bodies, glaciers sensu strictu are present in Turkey only on Mount Ararat and in the Buzul Mountains: in the other mountainous groups ice bodies are classified as glacierets due to their size and their morphology.

Part of these surviving glaciers can be considered remnants of the Little Ice Age (LIA) glaciation: geomorphological evidence of LIA moraines was found near Uludağ Peak (80 km south) from Erinç (1952), Birman (1968) and Zahno 
et al. (2010), on Mount Cilo (Kurter 1991) and Mount Ararat (Azzoni et al. 2017), whilst in the Eastern Black Sea Mountains moraines associated with a LIA advance appear to be absent (Akçar et al. 2008) suggesting dry and cold climatic conditions during the LIA (Hughes 2014).

\section{Evolution of Turkish glaciers}

As concerns recent glacier evolution, few comparable data are available for most Turkish glacier, due to the lack of multi-temporal high-resolution that permits a reliable mapping of small glaciers. Nevertheless, we chose to compare our inventory with the one produced by Sarıkaya and Tekeli (2014), as their outlines are publicly available as part of the Randolph Glacier Inventory (RGI). Despite the same overall glacier number (51), the glacier area $(12.28$ $\mathrm{km}^{2}$ compared to $11.50 \mathrm{~km}^{2}$ ) are higher in our inventory than in the RGI. The small number of glaciers permits a detailed assessment of these differences: 13 glaciers in the RGI are not in our inventory, as a result of extinction. Conversely, we listed 15 glaciers which were not included in the RGI. Additionally, 3 glaciers in the RGI underwent fragmentation in two separate glaciers each. If we exclude glaciers reported in our inventory but not in the RGI, glacier area in our inventory becomes $12.00 \mathrm{~km}^{2}$, which is still slightly higher. The remaining difference can be explained by the inclusion of debris covered areas on Mount Ararat, which is $1.7 \mathrm{~km}^{2}$ larger in our inventory (see Fig. 7). The improved classification of debris-covered areas here is supported by recent field observations presented in Azzoni et al. (2017, 2019).

Excluding Mount Ararat, all but four of the other small glaciers listed in the RGI have seen a reduction in area. The maximum reduction is $0.12 \mathrm{~km}^{2}$ for the Geverok Glacier in the southeastern Taurus mountains, which lost about a third of its size from $0.37 \mathrm{~km}^{2}$ to $0.25 \mathrm{~km}^{2}$. Among the four glaciers which saw an increase in their area, two have changes $<0.01 \mathrm{~km}^{2}$, while the Avucur Glacier in the Eastern Black Sea mountains has the largest positive change at $0.04 \mathrm{~km}^{2}$. These changes can also be explained by the differences in mapping debris cover; the uncertainty related to debris covered areas is unavoidable but likely reduced for

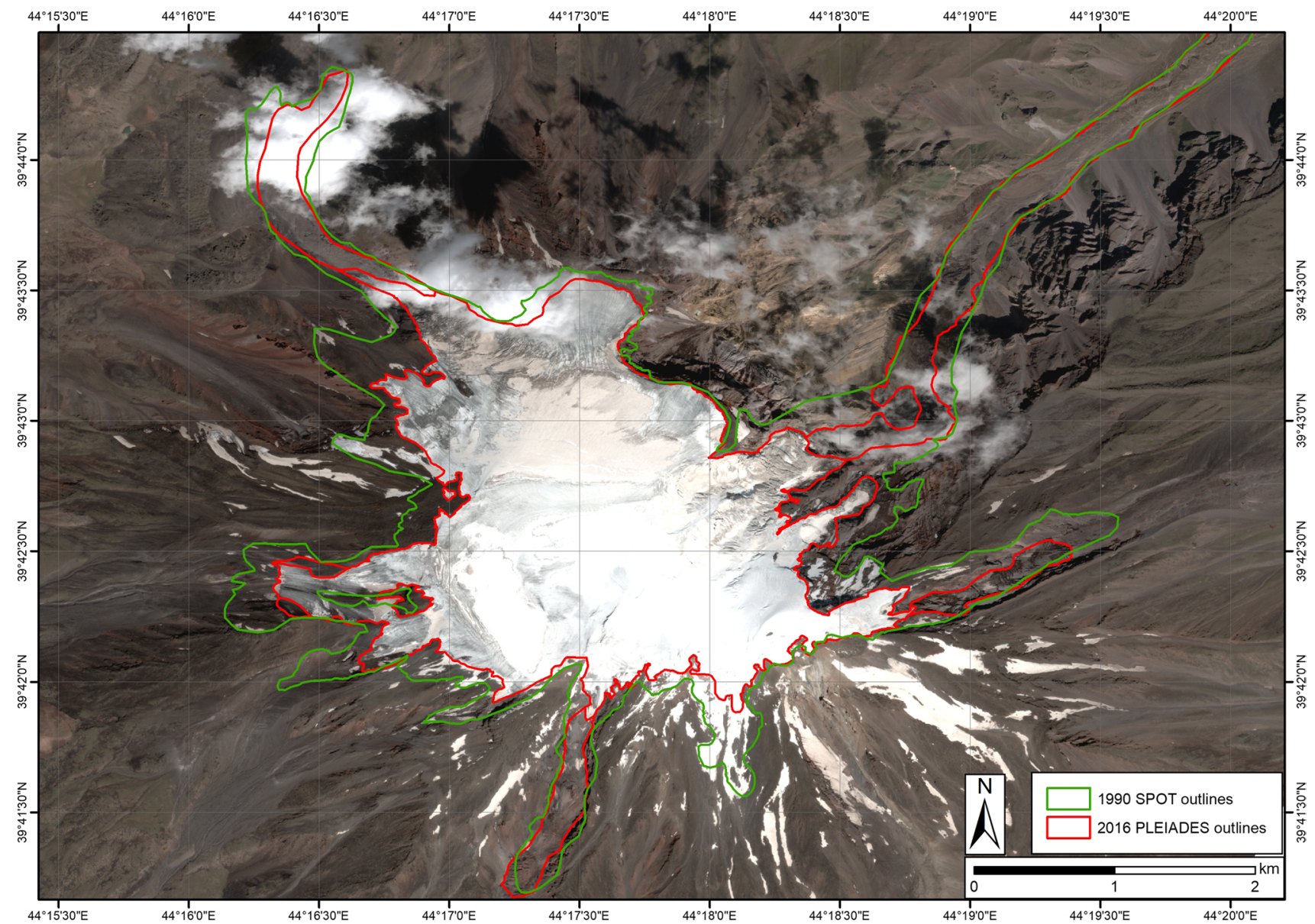

Fig. 7 Mt. Ararat glacier outline evolutions between 1990 and 2016 
our inventory, as the outlines were entirely produced using high-resolution $(\leq 1.5 \mathrm{~m})$ data.

The comparison between the two inventories (again excluding Mount Ararat) shows a weak relationship between glacier area and recession (see Fig. 8a). A decrease in area occurred at all elevations $<3750 \mathrm{~m}$ a.s.l. (except $3500 \mathrm{~m}$ a.s.l., see Fig. 8b). The largest changes occur between 2800 and $3450 \mathrm{~m}$ a.s.l. Changes are lower below $2800 \mathrm{~m}$ a.s.l., as few glaciers actually reach these elevations. At the higher elevations, positive changes might reflect different interpretations of the glacier accumulation basins. The total area loss of small Turkish glaciers from the previous inventory can be estimated at $0.76 \mathrm{~km}^{2}$. While it is difficult to estimate recession rates because the work by Sarkaya and Tekeli (2014) used images from different years (2003-2011), this value represents a speed up of glacier recession compared to their estimate of $0.07 \mathrm{~km}^{2} \mathrm{y}^{-1}$. However, taking into account the uncertainty related to glacier mapping and the added issues of debris cover, the time difference between the RGI and our inventory is relatively small to provide accurate estimates of changes. Over longer time scales, the comparison between our inventory and the previous reports of glacier area in the 1970s by Kurter (1991) and Yavaşlı et al. (2015), reveal approximately a $50 \%$ reduction.
Fig. 8 Glacier changes between this study and the Randolph Glacier Inventory (RGI) outlines produced by Sarıkaya and Tekeli (2014). a Glacier change with respect to glacier area. The area from the RGI is used as the dependent variable. b Glacier change at different elevation intervals (50 m elevation bins). Mt. Ararat is excluded from this comparison

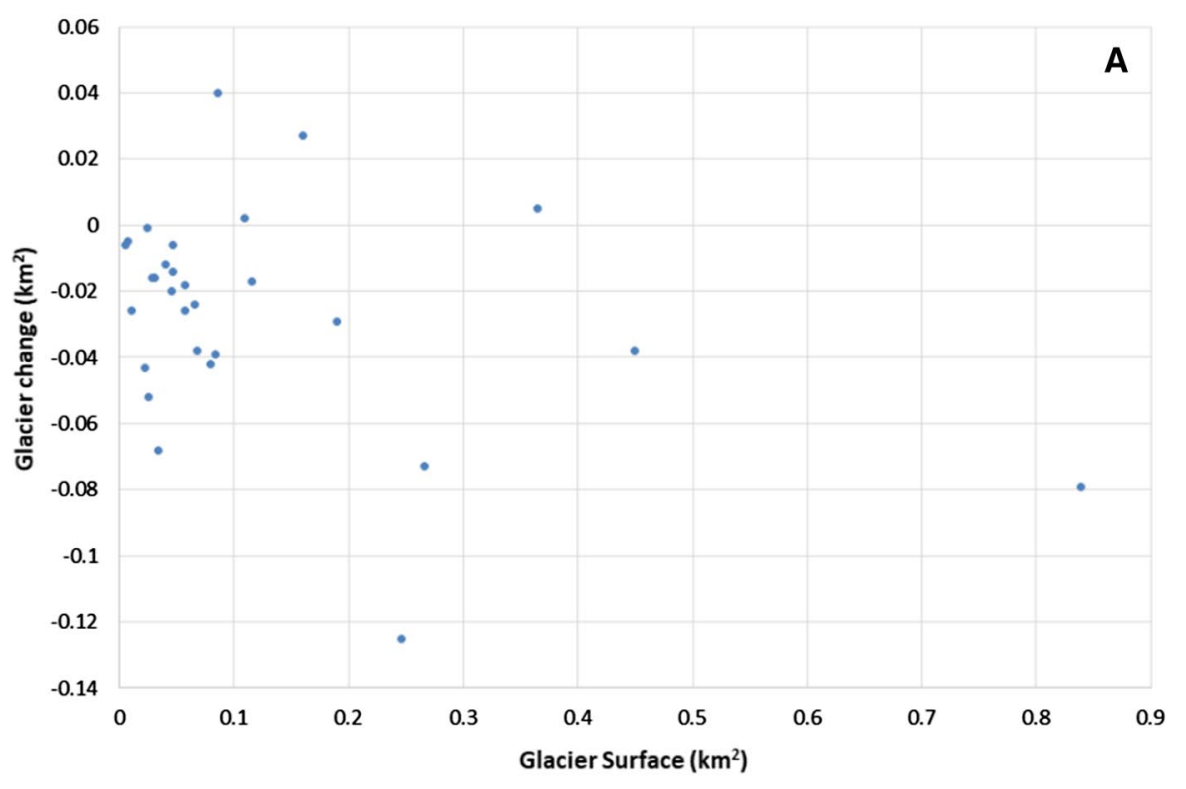

0.45

B

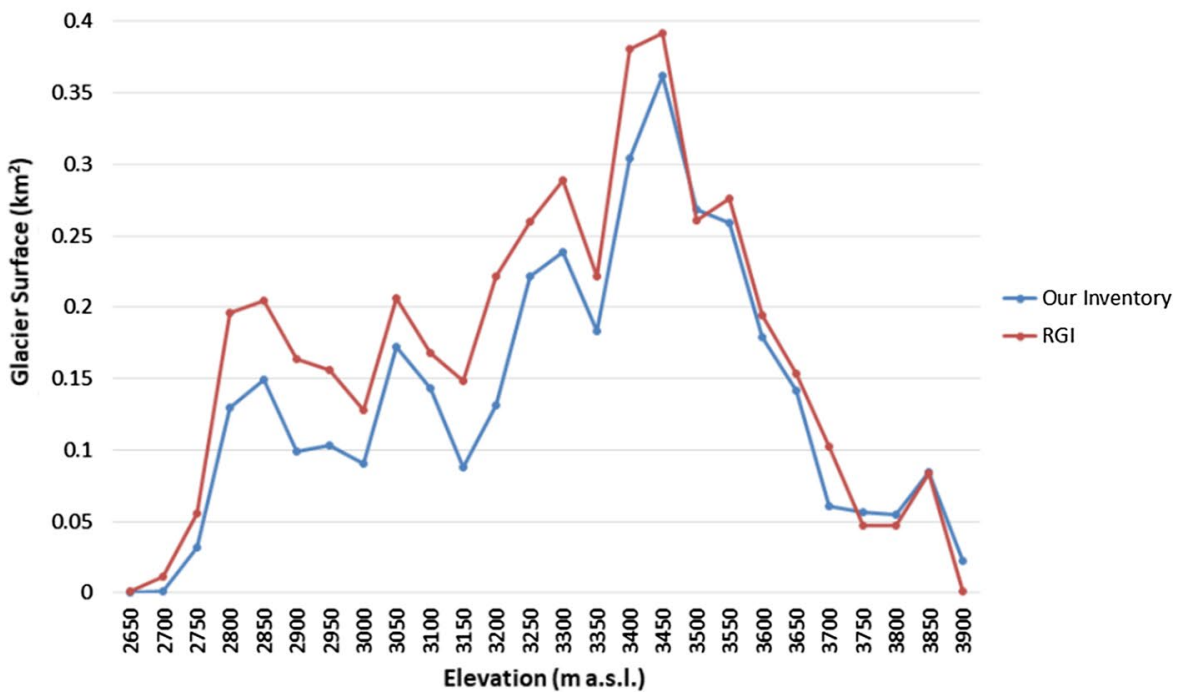


We have also considered the position of the snowline on the satellite images as a proxy for the Equilibrium Line Altitude (ELA) of Turkish glaciers. This altitude varies substantially moving from West toward East. On Munzur and Kaçkar Mountains, the ELA is difficult to estimate due to the morphology of these ice bodies. On Buzul Mountains, the ELA is about $3500 \mathrm{~m}$ a.s.l., while it reaches $4200 \mathrm{~m}$ a.s.l. on Mount Ararat.

To assess the evolution of Mount Ararat glacier, we redigitized outlines for 1990, 1994, 2000 and 2016. In 1990, the glacierized area of the volcano was $10.35 \mathrm{~km}^{2}$, whereas in 2016 the glacier covered $7.36 \mathrm{~km}^{2}$. In 26 years, the glacier shows a retreat of $2.99 \mathrm{~km}^{2},-29 \%$ of the initial value. The recession rate (i.e. glacier area change, reported as percentage of area lost per year) was $1.9 \%$ per year between 1990 and 1994, 1.4\% between 1994 and 2000 and $1.0 \%$ between 2000 and 2016. This apparent slow-down of glacier retreat can be partly decoupled from regional climate trends. In fact, the assessment of a long-term climate trend in the region revealed a general increase in measured air temperatures of about $+0.06{ }^{\circ} \mathrm{C}$ year ${ }^{-1}$ and no significant precipitation trends (Sarıkaya 2012). The slow-down can thus be traced back to the increasingly thick debris cover on the three main ice flows discharging ice from the ice cap. At $1.0 \%$ year $^{-1}$, the recession rate is still dramatically higher than the main glacierized mountain ranges of the world such as the Himalayas, Karakoram (Bolch et al. 2012) and Alps (Kääb et al. 2002; Gardent et al. 2014; Smiraglia et al. 2015) and comparable to the evolution of tropical glaciers such as in the Bolivian Andes (Cook et al. 2016) or Kilimanjaro (Cullen et al. 2013) and in the Mediterranean area (Hughes 2014).

\section{Conclusions}

This study presents the results of the a recent (2016-2017) high resolution inventory of the glaciers of Turkey with a focus on the evolution of Mount Ararat glaciation; We identified 51 glaciers, of which 8 can be considered glaciers sensu strictu, while 42 are glacierets, often surviving thanks to partial debris-cover.. Turkish glaciation sums up to 12.29 $\mathrm{km}^{2}$, and is dominated by Mount Ararat, which covers more than $60 \%$ of the area, while only three glaciers are larger than $0.5 \mathrm{~km}^{2}$. While recession rates from previous studies are difficult to quantify because of the different resolution of data used and the small size of glaciers which can cause large uncertainties owing to differences in interpretation, we estimated an area loss of $0.76 \mathrm{~km}^{2}$ from the Randolph Glacier Inventory, excluding Mount Ararat.

The use of high-resolution satellite images and the manual delineation of glacier outlines in our inventory should minimize errors in small glaciers or glacierets located in niches or gorges. In these cases, the use of medium-resolution satellite images (i.e. Landsat or Sentinel) prevents the correct interpretation of glacier outlines due to shadows and snow cover. Correct mapping of highly debris-covered areas remains challenging even if high-resolution source data are used. Nevertheless, the use of source data with highest possible resolution supports the future creation of glacier inventories, in particular in areas dominated by small glaciers or glacierets such as the majority of Turkey.

Acknowledgements Pleiades and SPOT data were provided by the European Space Agency (ESA, project ID: 32011). RSA Post-Doc is funded by DAR (Department of Regional Affairs) of the Presidency of the Council of Ministers of the Italian government (GlacioVAR Project).

\section{References}

Akçar N, Yavuz V, Ivy-Ochs S, Kubik PW, Vardar M, Schlüchter C (2008) A case for a down wasting mountain glacier during Termination I, Verçenik Valley, NE Turkey. J Quat Sci 23:273-285

Azzoni RS, Zerboni A, Pelfini M, Garzonio CA, Cioni R, Meraldi E, Smiraglia C, Diolaiuti GA (2017) Geomorphology of mount Ararat/Ağri Daği (Ağri Daği Milli Parki, Eastern Anatolia, Turkey). J Maps 13(2):182-190

Azzoni RS, Fugazza D, Zerboni A, Senese A, D'Agata C, Maragno D, Diolaiuti GA (2018) Evaluating high-resolution remote sensing data for reconstructing the recent evolution of supra glacial debris: a study in the Central Alps (Stelvio Park, Italy). Progress Phys Geogr Earth Env 42(1):3-23

Azzoni RS, Fugazza D, Garzonio CA, Nicoll K, Diolaiuti GA, Pelfini M, Zerboni A (2019) Geomorphological effects of the 1840 Ahora Gorge catastrophe on Mount Ararat (Eastern Turkey). Geomorphology 332:10-21

Bayrakdar C, Çıl̆̆ın Z, Döker MF, Canpolat E (2015) Evidence of an active glacier in the Munzur Mountains eastern Turkey. Turk J Earth Sci 24(1):56-71

Berthier E, Vincent C, Magnússon E, Gunnlaugsson ÁP, Pitte P, Le Meur E, Wagnon P et al (2014) Glacier topography and elevation changes derived from Pléiades sub-meter stereo images. Cryosphere 8(6):2275-2291

Birman JH (1968) Glacial reconnaissance inTurkey. Geol Soc Am Bull 79(8):1009-1026

Blumenthal MM (1958) From mount Ağrı to Kaçkar mountains. Die Alpen 34:125-137

Bolch T, Kulkarni A, Kääb A, Huggel C, Paul F, Cogley JG, Bajracharya $S$ et al (2012) The state and fate of Himalayan glaciers. Science 336(6079):310-314

Çalışkan O, Gürgen G, Yılmaz E, Yeşilyurt S (2014) Debris-covered glaciers during glacial and interglacial periods on the Taurus Mountains (Turkey). Procedia Soc Behav Sci 120:716-721

Cook SJ, Kougkoulos I, Edwards LA, Dortch J, Hoffmann D (2016) Glacier change and glacial lake outburst flood risk in the Bolivian Andes. The Cryosphere 10:2399-2413

Cullen NJ, Sirguey P, Mölg T, Kaser G, Winkler M, Fitzsimons SJ (2013) A century of ice retreat on Kilimanjaro: the mapping reloaded. The Cryosphere 7:419-431

Diolaiuti GA, Azzoni RS, D’Agata C, Maragno D, Fugazza D, Vagliasindi M, Pecci M (2019) Present extent, features and regional distribution of Italian glaciers. La Houille Blanche 5-6:159-175

Erinç S (1952) Glacial evidences of the climatic variations in Turkey. Geogr Ann 34:89-98 
Gardent M, Rabatel A, Dedieu JP, Deline P (2000s) Multitemporal glacier inventory of the French Alps from the late 1960s to the late 2000s. Glob Planet Change 120:24-37

Giorgi F, Lionello P (2008) (2008): Climate change projections for the Mediterranean region. Glob Planet Change 63:90-104

González Trueba JJ, Martín MR, Martínez De Pisón E, Serrano E (2008) "Little Ice Age" glaciation and 489 current glaciers in the Iberian Peninsula. Holocene 18:551-568

Gürgen G, Çalışkan O, Yılmaz E, Yeşilyurt S (2010) Yedigöller platosu ve Emli vadisinde (Aladağlar) döküntü örtülü buzullar. J N World Sci Acad NEWSSA 5:98-116

Holzer N, Vijay S, Yao T, Xu B, Buchroithner M, Bolch T (2015) Four decades of glacier variations at Muztagh Ata (eastern Pamir): a multi-sensor study including Hexagon KH-9 and Pléiades data. The Cryosphere 9:2071-2088

Horvath E (1975) Glaciers of Turkey, Armenian S.S.R. and Iran. In: Field WO (ed) Mountain glaciers of the Northern Hemisphere, pt. III Glaciers of Southern Asia: Hanover, N.H., U.S. Army Cold Regions Research and Engineering Laboratory, p 343359

Hughes PD (2009) Twenty-first century glaciers in the Prokletije Mountains, Albania. Arct Antarct Alp Res 41:455-459

Hughes PD (2014) Little Ice Age glaciers in the Mediterranean mountains. Mediterranée 122:63-79

Immerzeel WW, Van Beek LPH, Bierkens MFP (2010) Climate change will affect the Asian water towers. Science 328:1382-1385

IPCC (2013) IPCC Fifth Assessment Report: Climate Change. IPCC, Geneva, Switzerland

Kääb A, Paul F, Maisch M, Hoelzle M, Haeberli W (2002) The new remote-sensing-derived Swiss glacier inventory: II. First results. Ann Glaciol 34:362-366

Kurter A (1991) Glaciers of the Middle East and Africa-Glaciers of Turkey. In: Williams RS, Ferrigno JG (eds) Satellite Image Atlas of Glaciers of the World. United States Geological Survey Professional Paper, vol 1386-G-1, p 1-30

La Fontaine CV, Bryson RA, Wendland WM (1990) Airstream regions of North-Africa and the Mediterranean. J Clim 3:366-372

Paul F, Barry RG, Cogley JG, Frey H, Haeberli W, Ohmura A, Zemp $\mathrm{M}$ et al (2009) Recommendations for the compilation of glacier inventory data from digital sources. Ann Glaciol 50(53):119-126

Paul F, Frey H, Le Bris R (2011) A new glacier inventory for the European Alps from Landsat TM scenes of 2003: challenges and results. Ann Glaciol 52:144-152

Pfeffer W, Arendt A, Bliss A, Bolch T, Cogley J, Gardner A, Sharp M et al (2014) The Randolph glacier inventory: a globally complete inventory of glaciers. J Glaciol 60(221):537-552
Ruiz L, Berthier E, Masiokas M, Pitte P, Villalba R (2015) First surface velocity maps for glaciers of Monte Tronador, North Patagonian Andes, derived from sequential Pléiades satellite images. J Glaciol 61(229):908-922

Sarıkaya MA (2012) Recession of the ice cap on Mount Ağrı (Ararat), Turkey, from 1976 to 2011 and its climatic significance. J Asian Earth Sci 46:190-194

Sarıkaya MA, Tekeli AE (2014) Satellite inventory of the glaciers in Turkey. In: Kargel JS (ed) Global land Ice measurements from space. Springer Praxis Books, Heidelberg, pp 465-480

Sarıkaya MA, Zreda M, Çiner A (2009) Glaciations and paleoclimate of Mount Erciyes, central Turkey, since the Last Glacial Maximum, inferred from ${ }^{36} \mathrm{Cl}$ cosmogenic dating and glacier modeling. Quatern Sci Rev 28(23-24):2326-2341

Smiraglia C, Azzoni RS, Agata C, Maragno D, Fugazza D, Diolaiuti GA (2015) The evolution of the Italian glaciers from the previous database to the New Italian Inventory. Preliminary considerations and results. Geogr Fis Dinamica Quat 38(1):79-87

Takaku J, Tadono T, Tsutsui K, Ichikawa M (2016) Validation of" AW3D" global DSM generated from Alos Prism. ISPRS Ann Photogram Remote Sens Spatial Inf Sci 3:25

Türkeş M, Erlat E (2005) Climatological responses of winter precipitation in Turkey to variability of the North Atlantic Oscillation during the period 1930-2001. Theoret Appl Climatol 81(1-2):45-69

Vögtle T, Schilling K (1999) Digitizing maps. In: Bähr HP, Vögtle T (eds) GIS for environmental monitoring. Schweizerbart, Stuttgart, pp 201-216

Williams RS, Ferrigno JG (1998) Satellite image atlas of glaciers of the world: Glaciers of the Middle East and Africa. In: United States Geological Survey Professional Paper 1386-G. Washington, DC: United States Geological Government Printing Office, $\mathrm{p} 70$

Yavaşlı DD, Tucker CJ, Melocik KA (2015) Change in the glacier extent in Turkey during the Landsat Era. Remote Sens Environ 163:32-41

Zahno C, Akçar N, Yavuz V, Kubik PW, Schlüchter C (2010) Chronology of Late Pleistocene glacier variations at the Uludağ Mountain, NW Turkey. Quatern Sci Rev 29:1173-1187

Publisher's Note Springer Nature remains neutral with regard to jurisdictional claims in published maps and institutional affiliations. 